\title{
Comportamento das argamassas de revestimento no estado fresco, compostas com areia de britagem de rocha calcária e areia natural
}

\author{
Behavior of fresh-laid mortars composed of crushed \\ limestone sand and natural sand
}

\author{
Rosângela Basso Tokarski ${ }^{1}$, Adalberto Matoski ${ }^{1}$, \\ Luana Cechin ${ }^{1}$, Alessandra Monique Weber ${ }^{1}$
}

\footnotetext{
${ }^{1}$ Programa de Pós-Graduação em Engenharia Civil, Universidade Tecnológica Federal do Paraná - UTFPR, R. Dep. Heitor Alencar Furtado, 5000 - Campo Comprido, CEP 81280-340, Curitiba, PR, Brasil.

e-mail: rosangela.tokarski@ifsc.edu.br, adalberto@utfpr.edu.br, luhcechin@gmail.com, alessandramoniqueweber@gmail.com
}

\begin{abstract}
RESUMO
O objetivo desse trabalho é identificar o comportamento da areia de britagem de rocha calcária na argamassa de revestimento. Foram propostas cinco composições de traço, a primeira com $100 \%$ areia natural, que será usado como traço de referência, a segunda composição com $80 \%$ areia natural, e $20 \%$ areia de britagem de rocha calcária, o terceiro com $60 \%$ areia natural e $40 \%$ areia de britagem de rocha calcária, o quarto com $40 \%$ areia natural e $60 \%$ areia de britagem de rocha calcária, e o quinto com $20 \%$ areia natural e $80 \%$ areia de britagem de rocha calcária. Os traços das argamassas foram compostos com cimento, areia, água e aditivo plastificante, sem a presença da cal, e estas foram ensaiadas no estado fresco. Os resultados mostraram que os traços compostos com a areia de britagem de rocha calcária apresentaram melhor desempenho que o traço de referência, composto apenas com areia natural. O traço com $60 \%$ de areia natural e $40 \%$ de areia de britagem de rocha calcária apresentou melhor desempenho, tendo apresentado uma curva granulométrica dentro da zona ótima superior e inferior exigido pela norma. A relevância desse estudo se deve ao fato de que, a areia de britagem é um resíduo que gera um importante passivo ambiental. Portanto a utilização desse tipo de resíduo, possibilita a redução desse impacto ambiental.
\end{abstract}

Palavras-chave: Argamassa de revestimento. Areia natural. Areia de britagem de rocha calcária.

\begin{abstract}
The goal of this resarch is to identify the behavior of limestone crushed sand in coating mortar. Five trace compositions were proposed and tested: the first one made up of $100 \%$ natural sand, which will be used as reference trace, the second composition presented $80 \%$ natural sand and $20 \%$ limestone rock crushed sand, the third one $60 \%$ natural sand and $40 \%$ limestone rock crushed sand, the fourth one with $40 \%$ natural sand and $60 \%$ limestone rock crushed sand, and the fifth trace $20 \%$ natural sand and $80 \%$ limestone rock crushed sand. The mortar traces were composed of cement, sand, water and additive, without the presence of lime, and these were tested in the wet state and presented the following results: Composite traces with limestone rock crushed sand presented better performance than the reference trace, which had only natural sand. The traces with $60 \%$ natural sand and $40 \%$ limestone crushed sand showed better performance, and presented a grain size curve within the optimal upper and lower zone, as required by the standard rules. The relevance of this study is due to the fact that crushed sand is a waste that generates important environmental liability. Therefore, the use of this type of waste makes it possible to reduce this environmental impact.
\end{abstract}

Keywords: Coating mortar. Natural sand. Limestone rock crushed sand.

\section{INTRODUÇÃO}

Argamassas são materiais de construção com propriedades de aderência e endurecimento, obtidas a partir da mistura homogênea de um ou mais aglomerantes, agregado miúdo (areia) e água, podendo conter ainda aditivos e adições minerais. [1] 
O agregado miúdo (areia), é consumido no Brasil na ordem de 439 milhões de tonelada/ano, dados da ANEPAC (2015) - Associação Nacional de Empresas Produtoras de Agregados para Construção Civil [2]. Existe hoje a necessidade de encontrar um material alternativo para substituir a areia de rio, visto que o excesso de erosão dos rios causa danos ao meio ambiente e este precisa ser evitado. Pesquisadores estão encontrando diferentes materiais para substituir a areia de rios, e um dos principais materiais são os resíduos de pedreiras, ou pó de pedra. Usando diferentes proporções destes materiais; juntamente com a areia de rios, necessária na mistura das argamassas, pode-se obter bons resultados na aplicação e durabilidade das argamassas [3].

As características que mais distinguem as areias de britagem das areias de rio são a forma dos grãos, geralmente angulosa e com baixo grau de arredondamento; o elevado teor de material pulverulento (também chamado de filer de britagem); e a diferença de distribuição granulométrica, pois em função do tipo de processamento utilizado para a obtenção de agregados de britagem podem ocorrer falhas na produção de grãos em determinadas frações granulométricas. [4].

Uma vantagem das areias britadas é que elas apresentam menor variabilidade das propriedades e características, como granulometria, forma e, ainda, a ausência de impureza como matéria orgânica e presença de argila em torrões. Em contrapartida, a forma angulosa e muitas vezes lamelar de suas partículas, além da elevada presença de finos, podem influenciar nas propriedades das argamassas, principalmente na sua trabalhabilidade. Estas características dependem do tipo de rocha de origem e do tipos de britadores utilizados. [5]

A importância e a viabilidade do uso das areias de britagem nas argamassas de revestimento, é defendido por autores como $[6,7,8,9,10,11,12,13,14]$, estes mostram resultados positivos na aplicação destas argamassas.

As argamassas de revestimento apresentam várias propriedades, tanto no estado fresco como também no estado endurecido. Carasek [1] separa estas propriedades no estado fresco em: trabalhabilidade, consistência, plasticidade, retenção de água e consistência, coesão, exsudação, densidade de massa, adesão inicial. No estado endurecido as principais propriedades são a aderência e a elasticidade.

Para Souza e Lara [15], algumas destas propriedades estão interligadas tornando difícil a sua análise em separado, como por exemplo a consistência, a plasticidade e a trabalhabilidade, pois os fatores que influenciam uma influenciaram também as outras.

Para Carasek et. al. [5], a hipótese é de que a consistência das argamassas no estado fresco tem seu comportamento associado a parâmetros da areia como: ângulo de atrito e fator de empacotamento dos grãos. É de conhecimento que o empacotamento tem significativa influência sobre o índice de vazios, porosidade e massa unitária do agregado (na condição seca e solta), sendo, por sua vez, alterado pela forma e geometria das partículas, além da distribuição granulométrica.

Este estudo analisa as características físicas e químicas da areia de britagem de rocha calcária e da areia natural no estado solto, e tem como objetivo analisar e comparar o comportamento das argamassas no estado fresco, quando preparadas com diferentes porcentagens de areia de britagem de rocha calcária.

\section{MATERIAIS E MÉTODOS}

\subsection{Materiais}

Neste trabalho foi utilizado areia de britagem de rocha calcária, resíduo da extração desta rocha para a fabricação do cimento, proveniente de Rio Branco região metropolitana de Curitiba. Esta areia foi utilizada sem seleção previa de granulometria ou lavagem para retirada de material pulverulento, reproduzindo assim a forma como ela é oferecida ao mercado. A areia natural também é oriunda de rios da região metropolitana de Curitiba.

Foi utilizado o cimento Portland CP II F-32, optou-se por não utilizar a cal, e para manter a trabalhabilidade da argamassa foi utilizado um aditivo plastificante incorporador de ar Vedalit da marca Vedacit. Estes componentes estão caracterizados nas Tabelas 1 e 2 e 3 conforme dados fornecidos pelos fabricantes.

Os materiais foram caracterizados conforme instruções normativas brasileiras. As argamassas foram caracterizadas no estado fresco, seguindo normativas brasileiras e internacionais. Na Figura 1 são apresentadas as areias que foram usadas na pesquisa. 


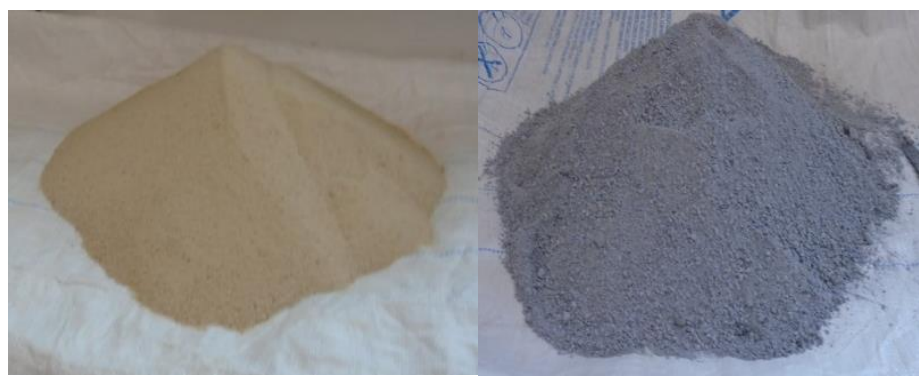

(a)

(b)

Figura 1: Areias usadas na pesquisa, (a)areia natural; (b)areia de britagem de rocha calcária.

Nas Tabela 1 estão descritas as características físicas e químicas do cimento fornecidas pelo fabricante.

Tabela 1: Características físicas e químicas do cimento Portland CP II F-32.

\begin{tabular}{|c|c|c|c|c|}
\hline \multicolumn{2}{|c|}{ PROPRIEDADES } & $\begin{array}{l}\text { MÉTODOS DE } \\
\text { ENSAIO }\end{array}$ & $\begin{array}{l}\text { CARACTERIZAÇÃO } \\
\text { DA AMOSTRA }\end{array}$ & $\begin{array}{l}\text { PARÂMETROS } \\
\text { NORMATIVOS DA } \\
\text { NBR 11578: } 1991\end{array}$ \\
\hline \multicolumn{2}{|c|}{ Massa unitária $\left(\mathrm{g} / \mathrm{cm}^{3}\right)$} & NBR NM 23: 2001 & 1,05 & - \\
\hline \multicolumn{2}{|c|}{ Massa específica $\left(\mathrm{g} / \mathrm{cm}^{3}\right)$} & NBR NM 23: 2001 & 2,97 & - \\
\hline \multicolumn{2}{|c|}{ Finura Blaine $\left(\mathrm{cm}^{2} / \mathrm{g}\right)$} & NBR NM 76: 1998 & 4380 & $\geq 2600$ \\
\hline \multicolumn{2}{|c|}{ Resíduo na peneira \# 200, 75mm (\%) } & NBR 11579: 1991 & 0,8 & $\leq 12$ \\
\hline \multicolumn{2}{|c|}{ Resíduo na peneira \# 325, $45 \mathrm{~mm} \mathrm{( \% )}$} & NBR 12826: 1993 & 5,8 & - \\
\hline \multicolumn{2}{|c|}{ Tempo de início de pega (h, min) } & NBR NM 65: 2003 & $2 \mathrm{~h}, 20 \mathrm{~min}$ & $\geq 1 \mathrm{~h}$ \\
\hline \multicolumn{2}{|c|}{ Tempo de fim de pega $(h, \min )$} & NBR NM 65: 2003 & $3 \mathrm{~h}, 00 \mathrm{~min}$ & $\leq 10 \mathrm{~h}$ (facultativo) \\
\hline \multirow{3}{*}{$\begin{array}{l}\text { Resistência à } \\
\text { compressão }\end{array}$} & 3 dias $(\mathrm{MPa})$ & \multirow{3}{*}{ NBR 7215: 1996} & 23,0 & $\geq 10$ \\
\hline & 7 dias $(\mathrm{MPa})$ & & 31,5 & $\geq 20$ \\
\hline & 28 dias $(\mathrm{MPa})$ & & 40,0 & $\geq 32$ \\
\hline \multicolumn{2}{|c|}{ Teor de $\mathrm{MgO}(\%)$} & NBR NM 14: 2012 & 1,04 & $\leq 6,5$ \\
\hline \multicolumn{2}{|c|}{ Teor de $\mathrm{SO}_{3}(\%)$} & NBR NM 14: 2012 & 2,65 & $\leq 4$ \\
\hline
\end{tabular}

Nas tabelas Estão descritas as características físicas e químicas do aditivo VEDALIT usado nas argamassas

Tabela 2: Características físicas e químicas do aditivo VEDALIT, fornecidas pelo fabricante.

\begin{tabular}{l|l}
\hline \multirow{2}{*}{ ITENS } & \multirow{2}{*}{ LIMITES } \\
\hline \multirow{2}{*}{ Composição básica } & Ressinato de sódio \\
\cline { 2 - 2 } & Copolímero acrílico em dispersão aquosa \\
\hline PH & 11 a 11,6 \\
\hline Resina vegetal & $3 \%$ a $3,8 \%$ \\
\hline Hidróxido de sódio & $0,35 \%$ a $0,4 \%$ \\
\hline Breu & $1 \%$ a $1,3 \%$ \\
\hline \multirow{2}{*}{ Materiais incompatíveis } & Solventes \\
\cline { 2 - 2 } & Ácidos \\
\hline \multirow{2}{*}{$\begin{array}{l}\text { Produtos perigosos da } \\
\text { decomposição }\end{array}$} & Oxido de carbono \\
\cline { 2 - 2 } & Monóxido de carbono \\
\hline Densidade & 1,03 g/cm 3 \\
\hline Aparência & Liquido escuro isento de cloretos \\
\hline
\end{tabular}

Os revestimentos de argamassas podem apresentar diversos tipos de manifestações patológicas que prejudicam a sua estanqueidade, durabilidade e estética.

Segundo Carasek [1], vesículas podem ser formadas no revestimento, causadas pela hidratação retardada do óxido de cálcio não hidratado presente na cal hidratada (o interior da vesícula é branco), a carbonatação insuficiente da cal, dificultada por clima seco e temperatura elevada ou por ação do vento pode causar pulverulência na argamassa permitindo que o revestimento solte da parede. A cal por ser expansiva pode causar porosidade no revestimento, permitindo assim uma maior infiltração de umidade causando patologias como umidade excessiva, manchas e desprendimento do revestimento. 
A substituição da cal pelo aditivo plastificante e incorporador de ar, contribui para que estas patologias, não aconteçam, sem prejudicar as características e propriedades finais das argamassas. Na tabela 3 fornecida pelo fabricante esta demonstrado que o ar incorporado e a consistência das argamassa aumentam com o aditivo, estas duas propriedades contribuem para a qualidade da plasticidade das argamassas.

Na Tabela 3 esta demonstrado também que a resistência a aderência da argamassa aumenta com o uso do aditivo substituindo a cal. O aditivo foi usado em quantidade proporcional ao cimento conforme especificações do fabricante, como a quantidade de cimento foi mantida constante para todos os traços, conforme descrito na tabela 4, a quantidade de aditivo também ficou a mesma em todos os traços.

A quantidade do aditivo, cimento e água foi mantido constante para fazer a análise do comportamento da areia de britagem de rocha calcária e a areia natural em diferentes quantidades sem a interferência dos demais materiais.

Tabela 3: Características físicas e mecânicas do aditivo VEDALIT, fornecidas pelo fabricante.

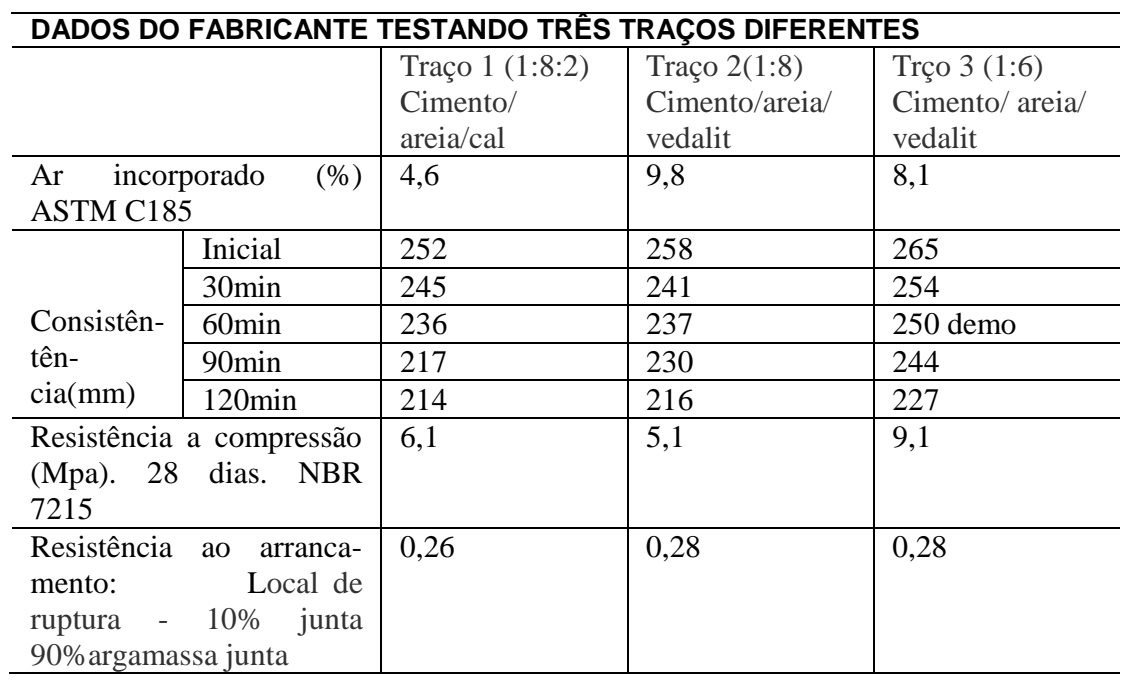

\subsection{Caracterização das areias}

A caracterização física das areias foi executada conforme orientações da ABNT - Associação Brasileira de Normas Técnicas. Foram realizados os seguintes ensaios Composição granulométrica ABNT NBR NM 248 [16], massa unitária e volume de vazios ABNT NBR NM 45[17], massa específica ABNT NBR NM 52 [18], teor de material pulverulento ABNT NBR NM 46 [19], inchamento ABNT NBR NM 6467 [20], absorção de água ABNT NBR NM 30 [21], impurezas orgânicas ABNT NBR NM 49 [22].

A caracterização química das areias foi realizada pelo método de Espectroscopia de Fluorescência de raios $\mathrm{X}$, o que permitiu a analisar as diferenças químicas das areias. A análise mineralógica foi realizada por Difratometria de raios X (DRX), e a forma e textura dos grãos foi estudada com fotos produzidas no MEVmicroscópio eletrônico de varredura.

\subsection{Caracterização das argamassas no estado fresco}

As argamassas foram preparadas em um agitador mecânico conforme recomendam as normas e foram ensaiadas para as seguintes propriedades: Índice de consistência ABNT NBR 13276 [23], teor de ar incorporado e densidade de massa ABNT NBR 13278 [24], retenção de água ASTM C 1506 [25], caracterização Reologia pelo método de Squeeze-Flow ABNT NBR 15839 [26], exsudação MR-6 (RILEM, 1982) [27]. As composições das areias usadas nos traços das argamassas também foram ensaiadas com relação a sua composição granulométrica.

Para a caracterização das argamassas foi mantido constante no traço o cimento a água e o aditivo, variando a quantidade de areia natural e de areia de britagem de rocha calcária. Estas composições estão apresentadas na Tabela 4. 
Tabela 4: Composição dos traços das argamassas.

\begin{tabular}{|c|c|c|c|c|c|c|c|}
\hline \multirow[t]{2}{*}{ TRAÇO } & \multicolumn{2}{|c|}{$\begin{array}{l}\text { COMPOSIÇÃO DO } \\
\text { AGREGADO MIÚDO (\%) }\end{array}$} & \multicolumn{5}{|c|}{ COMPOSIÇÃO DO TRAÇO - (1:3) } \\
\hline & AN & $\mathrm{ABRC}$ & Cimento & $\begin{array}{l}\text { Agregado } \\
\text { miúdo }\end{array}$ & Água & $\begin{array}{l}\text { Água/material } \\
\text { seco }\end{array}$ & $\begin{array}{l}\text { Aditivo } \\
(\mathrm{ml})\end{array}$ \\
\hline T-I & 100 & 0 & 1 & 3 & 0,8 & 0027 & 1 \\
\hline T-II & 80 & 20 & 1 & 3 & 0,8 & 0,27 & 1 \\
\hline T-III & 60 & 40 & 1 & 3 & 0,8 & 0,27 & 1 \\
\hline T-IV & 40 & 60 & 1 & 3 & 0,8 & 0,27 & 1 \\
\hline $\mathrm{T}-\mathrm{V}$ & 20 & 80 & 1 & 3 & 0,8 & 0,27 & 1 \\
\hline & \multicolumn{7}{|c|}{ Legenda- Traços e areias } \\
\hline T-I & \multicolumn{7}{|c|}{ Traço $1-1000 \%$ de areia natural } \\
\hline T-II & \multicolumn{7}{|c|}{ Traço $2-80 \%$ areia natural e $20 \%$ areia de britagem de rocha calcária } \\
\hline T-III & \multicolumn{7}{|c|}{ Traço $3-60 \%$ areia natural e $40 \%$ areia de britagem de rocha calcária } \\
\hline T-IV & \multicolumn{7}{|c|}{ Traço $4-40 \%$ areia natural e $60 \%$ areia de britagem de rocha calcária } \\
\hline $\mathrm{T}-\mathrm{V}$ & \multicolumn{7}{|c|}{ Traço $5-20 \%$ areia natural e $80 \%$ areia de britagem de rocha calcária } \\
\hline AN. & \multicolumn{7}{|c|}{ Areia Natural } \\
\hline ABRC & \multicolumn{7}{|c|}{ Areia de Britagem de Rocha Calcária } \\
\hline
\end{tabular}

\section{RESULTADO E DISCUSÕES}

Neste item serão apresentados os resultados obtidos pela realização dos ensaios, justificando e fazendo um comparativo com outros autores sempre que possível.

\subsection{Caracterização das areias}

As areias foram caracterizadas quanto a sua composição granulométrica, esta caracterização, foi realizada após a lavagem das areias para o levantamento do ensaio de material pulverulento. .

Os resultados destas análises granulometrias estão descritos na Figura 2, e quantificados na Tabela 5.

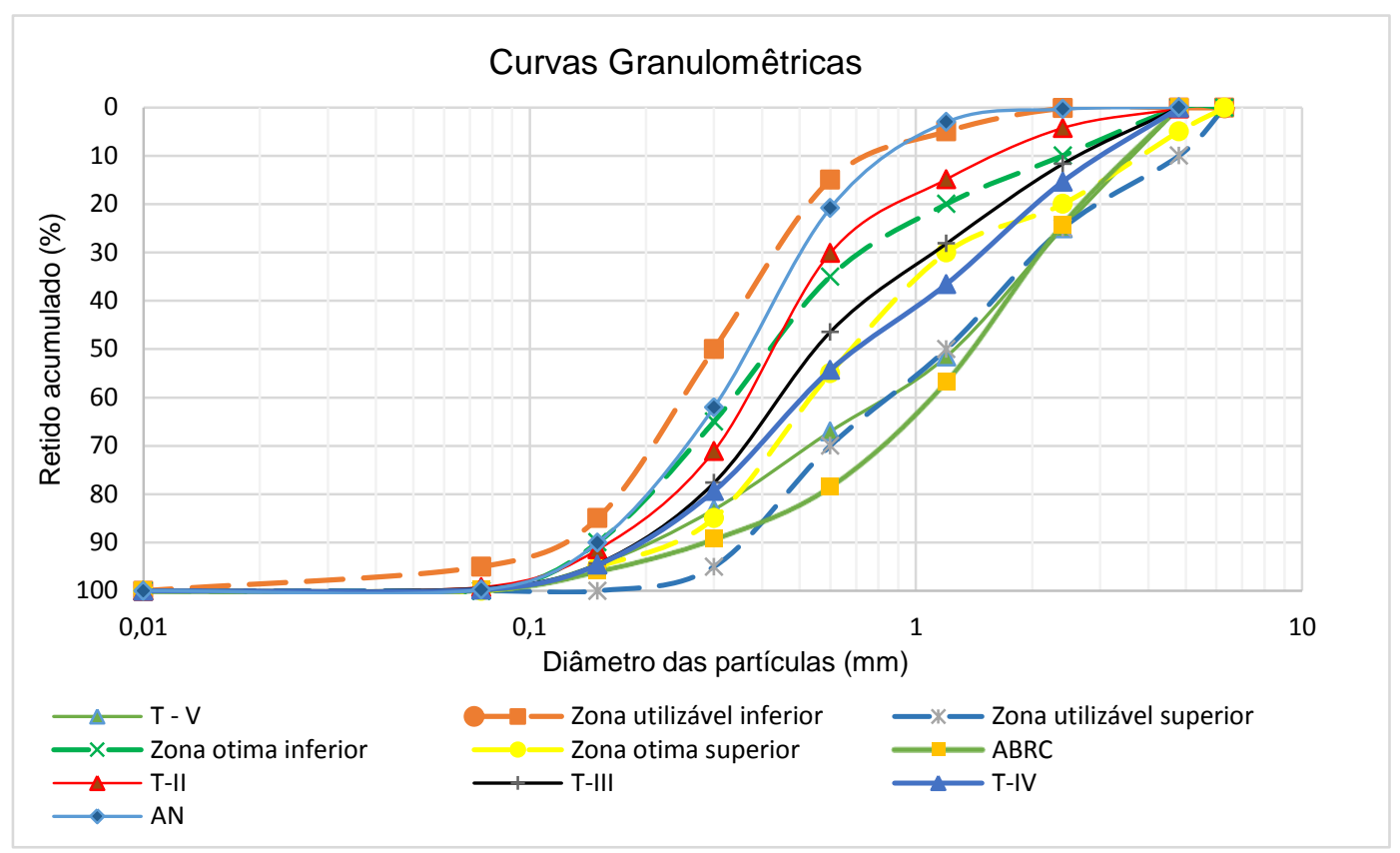

Figura 2: Curva granulométrica das areias e das composições da areia natural com a areia de britagem de rocha calcária.

As curvas granulométricas apresentadas na Figura 2 indicam que a composição da areia de britagem de rocha calcária com a areia natural favorece a granulometria dos agregados nas argamassas, pois a compensação entre os diâmetros dos grãos contribui para a homogeneidade do material. Observa-se ainda que a composição utilizada no traço T-III (60\% de areia natural e 40\% de areia de britagem) fica localizado no gráfico entre as zonas ótimas inferior e superior. 
Tabela 5: Índices físicos das areias e das composições das mesmas.

\begin{tabular}{l|l|l|l|l|l|l}
\hline & ABRC & AN & T-II & T-III & T-IV & T-V \\
\hline MF & 4,14 & 2,72 & 3,11 & 3,50 & 3,80 & 4,21 \\
\hline DMC $(\mathrm{mm})$ & 4,8 & 1,2 & 2,40 & 4,80 & 4,80 & 4,80 \\
\hline MP $(\%)$ & 14,55 & 4,78 & 11,81 & 8,69 & 12,33 & 12,01 \\
\hline Legenda & Módulo de finura \\
\hline MF & Dimensão máxima característica dos grãos \\
\hline DMC & Material pulverulento AN - 3\% a 5\% ABRC- 10\% a 12\% \\
\hline MP
\end{tabular}

Conforme pôde-se observar o material pulverulento da areia de britagem de rocha calcária é 14,55\%, valor esse acima do permitido pela norma ABNT NBR 7211 (2005) [28], que é de 12\%. No resultado apresentado pela análise a areia natural esta dentro do intervalo permitido por norma. A análise da composição das duas areias nas proporções propostas pela pesquisa indicam a compensação granulométrica entre elas diminuindo os níveis de material pulverulento aos limites permitidos pela norma.

Observa-se que o módulo de finura obtido para a areia de britagem apresenta valor acima do permitido pela norma, que para a areia grossa deveria ser $\leq \mathrm{a} 3,5$. A areia natural é classificada como ótima pois apresenta modulo de finura de 2,72, entre 2,2 e 2,9 indicado pela norma. Assim verifica-se na Tabela 5 que os traços T-II e T-III estão dentro da zona utilizável conforme determina a norma. Observa-se ainda que os traços TIV e TV, ficam acima do índice utilizável exigido por norma que é entre 2,90 e 3,50.

Na Tabela 6 estão apresentados os resultados da caracterização física das areias.

Tabela 6: Índices físicos da areia de britagem de rocha calcária e da areia natural

\begin{tabular}{l|l|l}
\hline INDICES FiSICOS. & AN & \multicolumn{1}{|c}{ ABRC } \\
\hline Absorção de água $(\%)$ & 0,75 & 2,95 \\
\hline Massa especifica aparente do agregado seco $-\mathrm{d}_{1}\left(\mathrm{~g} / \mathrm{cm}^{3}\right)$ & 2,25 & 2,73 \\
\hline Massa especifica do agregado saturado superfície seca $-\mathrm{d}_{2}\left(\mathrm{~g} / \mathrm{cm}^{3}\right)$ & 2,25 & 2,82 \\
\hline Massa especifica $\left.-\mathrm{d}_{3}\left(\mathrm{~g} / \mathrm{cm}^{3}\right)\right)$ & 2,26 & 2,99 \\
\hline Massa unitária do agregado seco - $\rho_{\mathrm{a}}\left(\mathrm{Kg} / \mathrm{dm}^{3}\right)$ & 1,61 & 1,77 \\
\hline Massa unitária do agregado saturado superfície seca $\rho_{\text {as }}\left(\mathrm{kg} / \mathrm{dm}^{3}\right)$ & 1,62 & 1,83 \\
\hline Índice de volume de vazios $(\%)$ & 28,43 & 34,75 \\
\hline Índice de inchamento $(\%)$ & 1,47 & 1,42 \\
\hline Umidade crítica $(\%)$ & 1,7 & 3,20 \\
\hline Impurezas orgânicas $-(\%)$ & 0 & 0 \\
\hline Umidade superficial $(\%)$ & 5,39 & 8,40 \\
\hline
\end{tabular}

Os índices físicos estudados comparados a dados de outros autores, [11, 8, 6, 29], são semelhantes aos valores apresentados por estes autores em seus trabalhos. A areia de britagem apresenta índices mais elevados que a areia natural nas massas especificas na ordem de 32,30\% maior, e nas massas unitárias na ordem de $11,48 \%$ maior, que contribuirão para elevar as massas especificas e unitárias das argamassas e também a sua densidade de massa A absorção de água pelos grãos é maior na areia de britagem em função da quantidade de finos que ela possuí.

Comparando com as areias estudas por Carasek et. al. [5], apresentam massas específicas menores $\left(2,72\right.$ a $\left.2,93 \mathrm{~g} / \mathrm{cm}^{3}\right)$ enquanto a areia de britagem de rocha calcária apresenta massa específica $=2,99 \mathrm{~g} / \mathrm{cm}^{3} . \mathrm{O}$ mesmo trabalho apresenta massas unitárias de 1,26 a $1,53 \mathrm{~g} / \mathrm{cm}^{3}$, e a massa unitária da areia de britagem de rocha calcária é $1,83 \mathrm{~g} / \mathrm{cm}^{3}$.

A umidade crítica é o ponto onde o agregado passa a não mais absorver água ou também onde a absorção tende a constância, indicando assim o ponto em que a massa se torna constante não aumentando mais de volume. Está demonstrado nos índices encontrados na Tabela 6, que a umidade crítica é maior na areia de britagem de rocha calcária do que na areia natural mostrando que elas atingem constância de volume em momentos diferentes com umidades diferentes, podendo influenciar na consistência e trabalhabilidade da argamassa.

As análises química e mineralógica das areias realizada pela espectroscopia de raios X e Difratometria de raios X são apresentadas a seguir. A Tabela 7 descreve a espectroscopia de raios X, e a comparação destes resultados com a areia do IPT, recomendada para uso em argamassas, e com o cimento. Pode-se assim identificar as diferenças entre as areias e a proximidade de alguns componentes da areia de britagem de rocha calcária com os componentes do cimento. 
Tabela 7: Composição químicos das areias e do cimento.

\begin{tabular}{|c|c|c|c|c|}
\hline COMPONENTES (\%) & AREIA IPT & AN & ABRC & CIMENTO \\
\hline $\mathrm{SiO}_{2}$ & 99,79 & 98,8 & 7,6 & 8,74 \\
\hline $\mathrm{CaO}$ & 0,004 & $<0,1$ & 43,4 & 61,27 \\
\hline $\mathrm{Fe}_{2} \mathrm{O}_{3}$ & 0,014 & 0,4 & 1,3 & 2,66 \\
\hline $\mathrm{Al}_{2} \mathrm{O}_{3}$ & 0,054 & 0,4 & 1,3 & 4,21 \\
\hline $\mathrm{K}_{2} \mathrm{O}$ & 0,007 & 0,1 & 0,4 & \\
\hline $\mathrm{MgO}$ & 0,003 & $<0,1$ & 7,9 & 3,70 \\
\hline $\mathrm{TiO}_{2}$ & 0,026 & 0,1 & 0,1 & \\
\hline $\mathrm{Cr}_{2} \mathrm{O}_{3}$ & & $<0,1$ & - & \\
\hline $\mathrm{ZrO}_{2}$ & 0,01 & $<0,1$ & - & \\
\hline $\mathrm{SO}_{3}$ & & - & 0,1 & 2,70 \\
\hline $\mathrm{Na}_{2} \mathrm{O}$ & 0,002 & - & 0,1 & \\
\hline $\mathrm{MnO}$ & & - & $<0,1$ & \\
\hline $\mathrm{SrO}$ & & - & $<0,1$ & \\
\hline $\mathrm{P}_{2} \mathrm{O}_{5}$ & & - & $<0,1$ & \\
\hline $\mathrm{CaO} 1$ & & & & 0,59 \\
\hline R. Ins & & & & 1,43 \\
\hline Eq. Alc & & & & 0,72 \\
\hline P.F. & 0,06 & 0,11 & 37,64 & 4,76 \\
\hline \multicolumn{5}{|l|}{ PEGA (h:min) } \\
\hline Inicio & & & & $4: 18$ \\
\hline Fim & & & & $5: 02$ \\
\hline
\end{tabular}

Em relação aos resultados obtidos observou-se que a areia natural é classificada como quartzosa conforme classificação do IPT. A areia de britagem contém, um alto teor de $\mathrm{CaO}$, este componente permite classificar a mesma como uma areia calcária. $\mathrm{O}$ alto índice de $\mathrm{CaO}$ na areia de britagem compostos com os demais itens da areia podem fazer com que ela modifique algumas características de reação do cimento no tempo e forma da pega da argamassa.

A análise mineralógica realizada através da difratometria de raios X (DRX) é demonstrada na Tabela 8 e na Figura 3, permitem observar os diferentes picos de cristalinidade das areias e sua composição.

Tabela 8: Análise mineralógica das areias.

\begin{tabular}{c|c|c|c}
\hline POSIÇÃO EM O & CODIGO & FORMULA QUIMICA & MINERAL \\
\hline \multicolumn{5}{c}{ Areia de britagem de rocha calcária } \\
\hline 31-segundo maior pico & 110078 & $\mathrm{CaMg}\left(\mathrm{CO}_{3}\right)_{2}$, & Dolomita \\
\hline 29- maior pico & 240027 & $\mathrm{CaCO}_{3}$ & Calcita \\
\hline 20-terceio maior pico & 461045 & $\mathrm{SiO}_{2}$ & Quartzo \\
\hline Vários picos dispersos & 291489 & $\mathrm{Al}_{4} \mathrm{Si}_{4} \mathrm{OH}_{8} \mathrm{O}_{10} .8 \mathrm{H}_{2} \mathrm{O}$ & Haloisita hidratado \\
\hline \multicolumn{5}{c}{ Areia natural } \\
\hline 26-maior pico & $46-1045$ & $\mathrm{SiO}_{2}$ & Quartzo \\
\hline 20 segundo maior pico & $38-0360$ & $\mathrm{SiO}_{2}$ & Moganite \\
\hline Vários picos dispersos & $38-0443$ & $\mathrm{Al}_{2} \mathrm{O}_{3}\left(2 \mathrm{SiO}_{2}\right) 3 \mathrm{H}_{2} \mathrm{O}$ & Alofa (Allophane) \\
\hline
\end{tabular}

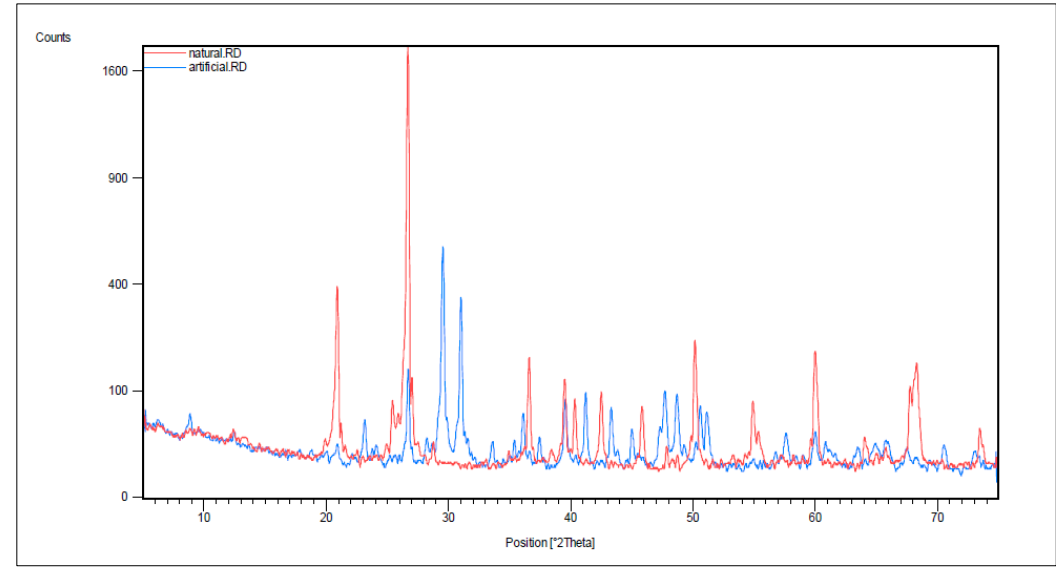

Figura 3: Difratograma de raios $X$ das areias, em vermelho areia natural, em azul areia de britagem de rocha calcária. 
Na Tabela 8 em conjunto com a Figura 3 observa-se que o maior pico do difratograma da areia natural é de $\mathrm{SiO}_{2}$ (quartzo e moganite) demonstrando assim a característica quartzosa desta areia. A areia de britagem apresenta seu maior pico composto por calcita, seguido de dolomita, o quartzo está presente no terceiro maior pico da areia de britagem. A intensidade máxima de amplitude do pico da areia natural é 4 vezes maior que a amplitude máxima do pico da areia de britagem, os componentes encontrados pela difratometria diferem entre as areias, sendo que dos principais componentes, o único que se aproxima e o quartzo que apresenta na areia de britagem um pico 10 vezes menor que na areia natural. A areia natural possui picos mais intensos com menor distribuição, e a areia de britagem de rocha calcária possui picos menores com uma amplitude de distribuição maior, e também mais componentes se destacam. As duas areias apresentam uma configuração cristalina.

Quanto a forma e textura dos grãos, fotos feitas pelo Microscópio Eletrônico de Varredura -MEV(Figura 4), pode-se constatar a rugosidade e a presença de ângulos agudos da areia de britagem de rocha calcária, enquanto a areia natural apresenta grãos mais lisos e arredondados.

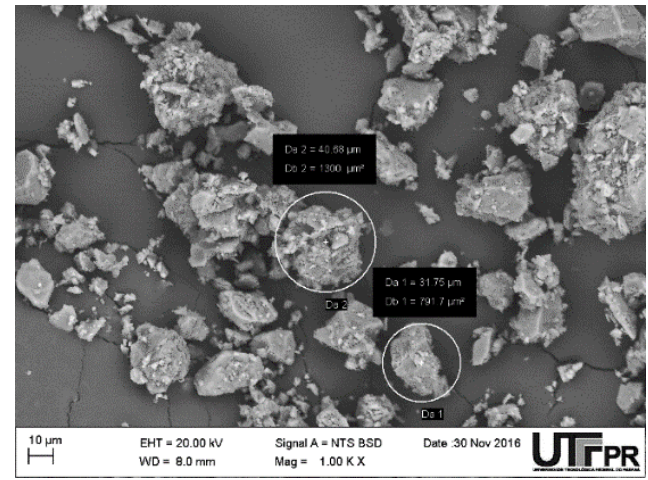

(a1)

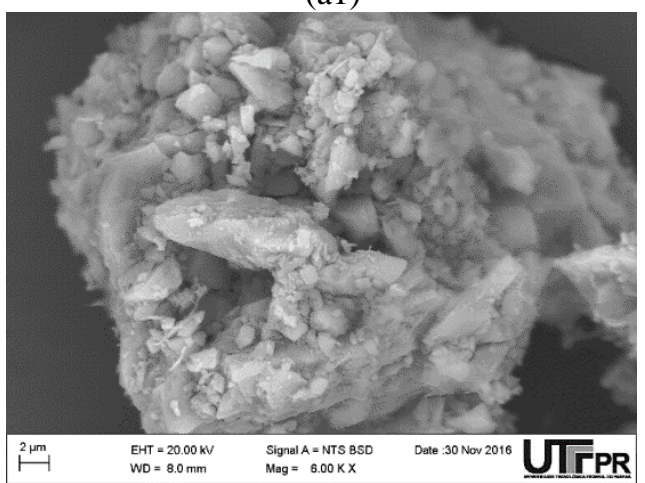

(a2)

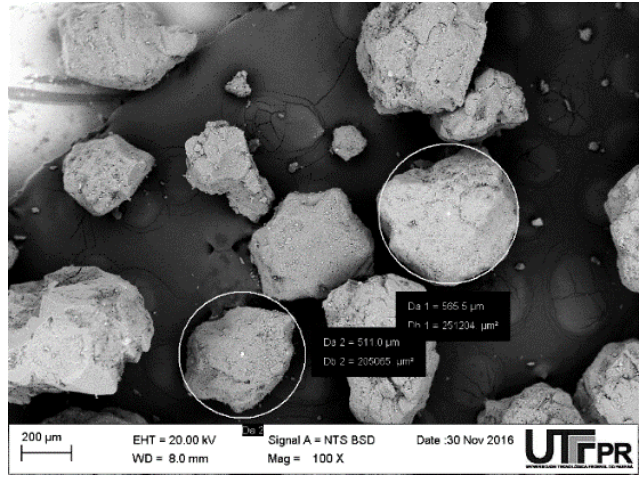

(b1)

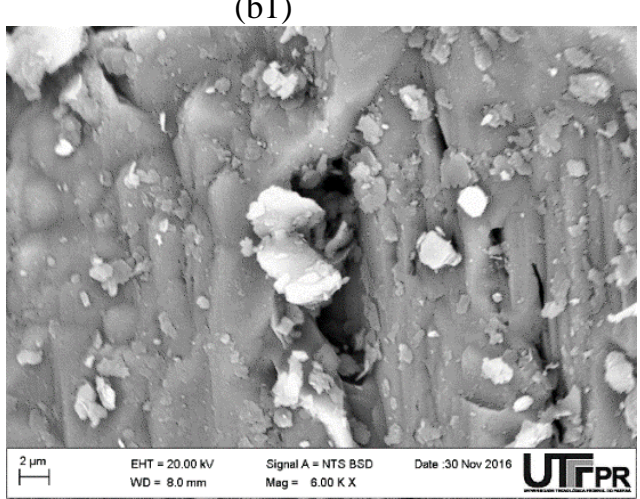

(b2)

Figura 4: Fotos das areias natural e de britagem de rocha calcária realizadas pelo MEV.

A foto (a1) revela com nitidez a forma irregular e ângulos agudos, bem como a elevada rugosidade superficial perceptível da areia de britagem, enquanto a areia natural foto (b2) apresenta uma forma arredondada sem rugosidade, conclui-se portanto que a compacidade do material aumenta, se o seu grão for mais arredondado. A área específica das areias também é afetada pelos parâmetros textuais dos grãos sendo que grãos mais rugosos fornecem maiores áreas específicas, porém não é possível fazer uma correlação da área específica com o empacotamento dos grãos.

A forma dos grãos das areias influência de forma marcante no empacotamento das partículas, afirma Arnold [6] na conclusão de seus trabalhos. O fator de empacotamento das partículas, propriedade importante oriunda da forma das areais, apresenta alta relação com a consistência das mesmas de forma que quanto maior o fator de empacotamento, maior a consistência das argamassas. [30]. Os parâmetros texturais das areias vão exercer uma forte influência no índice de vazios das areias, influenciando estes parâmetros no teor de ar incorporado no estado fresco da argamassa, para Tristão [31] estes parâmetros podem influenciar mais que a própria granulometria dos grãos, quanto mais arredondados os grãos maior o índice de vazios das argamassas. 
$\mathrm{Na}$ foto (b2) observa-se a superfície lisa da partícula, comparando a foto (a2) da areia de britagem com (b2) da areia natural constatamos a evidência da rugosidade da areia de britagem de rocha calcária.

Argamassas produzidas com esta areia aumentam a sua consistência em função dos parâmetros textuais e da compensação granulométrica mais favorável em função da variação dos diâmetros da partícula, e com isso melhora a plasticidade, esta melhora pode não ser compensatória, pois a alta rugosidade e aresta afiadas dos grãos prejudica a aplicação da argamassa.

\subsection{Caracterização das argamassas}

O comportamento das argamassas no estado fresco é determinante para a durabilidade e qualidade dos revestimentos. Os resultados dos ensaios realizados nas argamassas estão descritos a seguir.

O índice de consistência das argamassas foi medido pelos ensaios da flow table e squeeze flow. Na Figura 5 esta representada por meio de gráfico os resultados obtidos pela flow table.

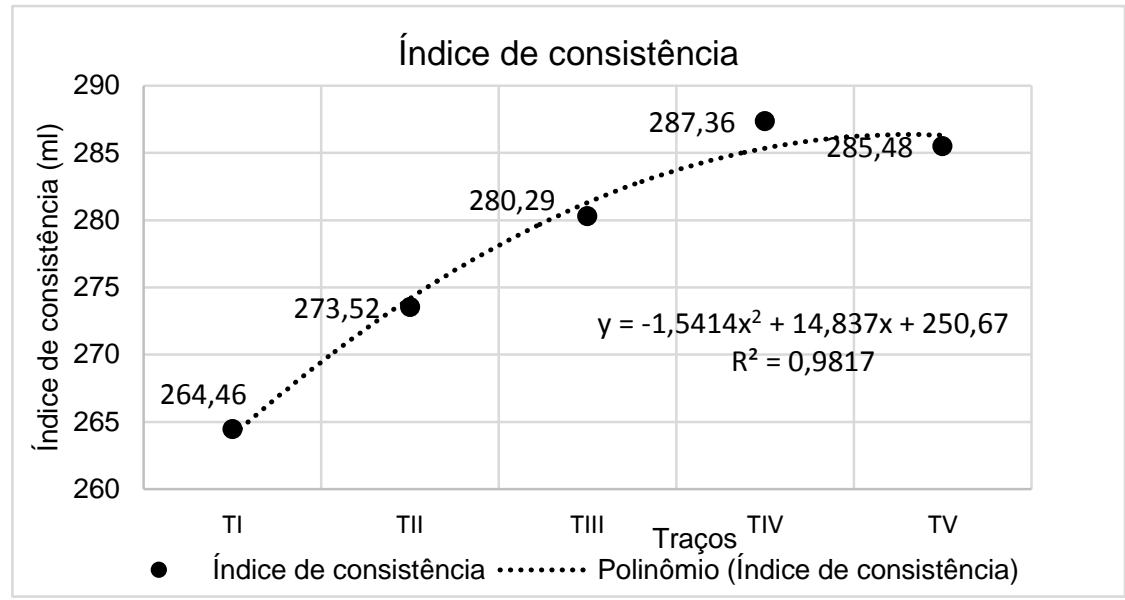

Figura 5: Índice de consistência das argamassas.

O índice de consistência das argamassas aumentou 21,02mm com o aumento da areia de britagem de rocha calcária nas argamassa. Pode-se atribuir este aumento ao fato da massa unitária da areia de britagem $\left(1,83 \mathrm{~kg} / \mathrm{dm}^{3}\right)$, ser maior que a massa unitária da areia natural $\left(1,63 \mathrm{~kg} / \mathrm{dm}^{3}\right)$. A massa unitária das areis desempenha um papel importante na consistência das argamassas, pois o aumento desta provoca um aumento substancial da fluidez das misturas, pois a massa unitária, esta ao mesmo tempo levando em conta o fator de empacotamento do conjunto particular de agregados, bem como todos os outros fatores que interferem neste parâmetro, ou seja forma e textura das partículas, sua distribuição granulométrica, se uniforme ou não, os teores de finos e frações finas presentes [5]. Estes fatores contribuíram para o aumento da massa unitária e consequentemente para o aumento da consistência com o aumento ada areia de britagem de rocha calcária nas argamassas. Na análise da linha de tendência obteve-se $\mathrm{R}^{2}=0,9817$ significando que $98,17 \%$ da variação do índice de consistência é explicado pela variação da quantidade de areia de britagem de rocha calcária nas argamassas.

As argamassas foram analisadas também em função de seu comportamento reológico pelo método de squeeze flow conforme determina a norma ABNT NBR 15839 [26], na Figura 6 estão representados as curvas com os resultados deste ensaio.

No traço T-I composto apenas por areia natural, observa-se que a força necessária para atingir a deformação máxima é 4 vezes menor que aos $15 \mathrm{~min}$, pois neste tempo de preparo a água constituinte da argamassa ainda não foi totalmente absorvida fazendo com que as partículas não ofereçam grande resistência ao rompimento das suas ligações, proporcionado um maior espalhamento da argamassa com uma força menor. No traço T-II composto de $20 \%$ de areia de britagem de rocha calcária e $80 \%$ de areia natural, aos 10 min a argamassa sofre uma deformação maior na ordem de 454\% que aos $15 \mathrm{~min}$, isto deve-se a maior rigidez da argamassa por perda de água durante os 5 min a mais de repouso. 

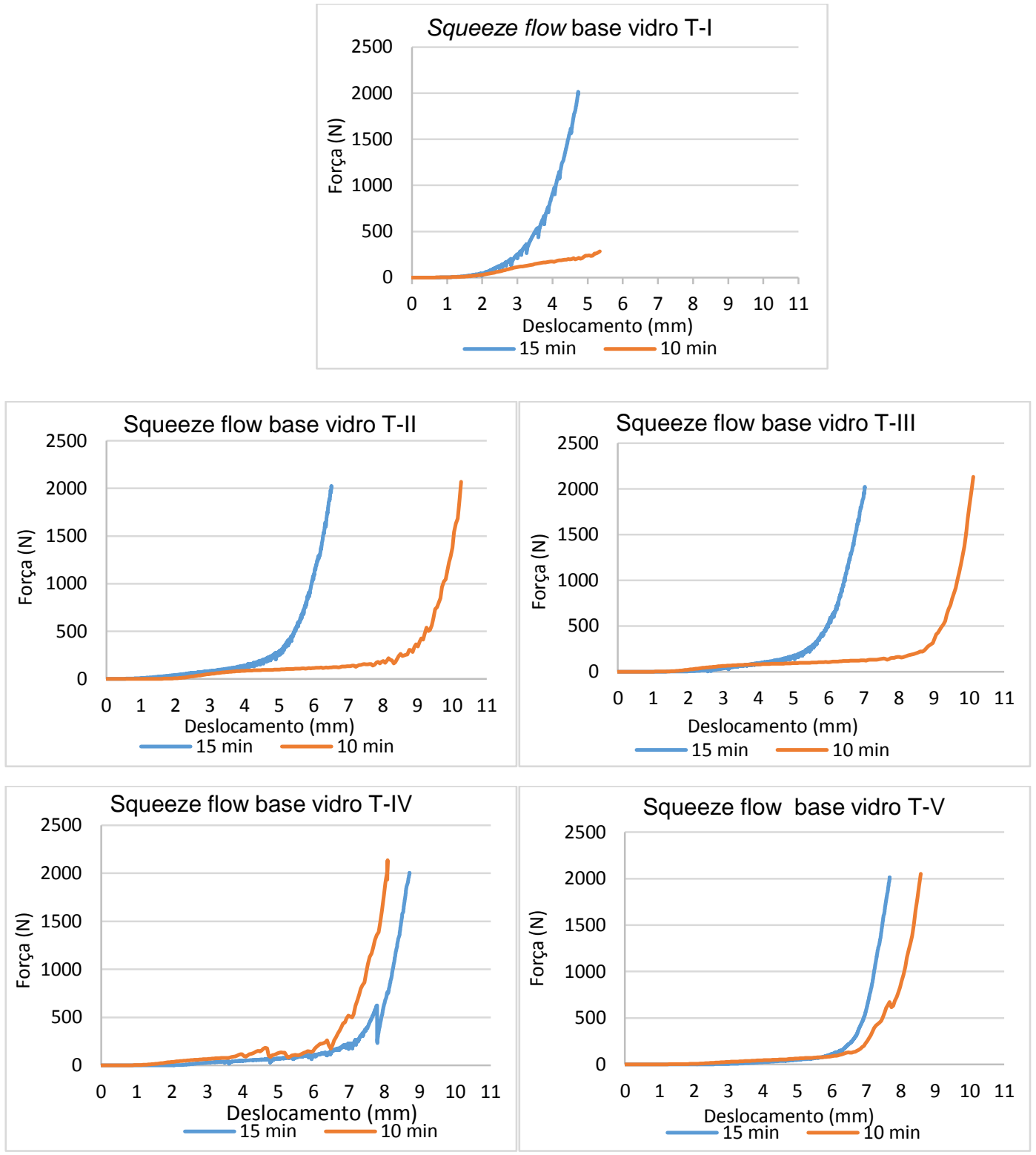

Figura 6: Gráficos do ensaio de squezze flow para os traços T-I, T-II, T-III, T-IV e T-V.

O traço T-III composto com $60 \%$ de areia natural e $40 \%$ arearia de britagem de rocha calcária teve um comportamento semelhante ao traço T-II nas medidas de deslocamento lidas aos 10 min, mas aos 15 min, o deslocamento do traço T-II foi 5\% menor para a mesma força final aplicada, fato este atribuído a menor retenção de água da argamassa com o aumento da percentagem de areia de britagem de rocha calcária na argamassa. No traço T-IV o comportamento da argamassa foi diferenciado em relação aos demais traços deslocando menos aos 10 min do que aos 15 min com uma deformação não uniforme, causada pelos grãos de areia de granulometria maior devido ao aumento no traço da areia de britagem, esta falta de uniformidade no deslocamento do traço T-IV pode ser atribuída também a forma irregular dos grãos da areia de britagem de rocha calcária, que oferecem uma maior resistência ao deslizamento da argamassa. O maior deslocamento do traço T-IV também é $20 \%$ menor que o maior deslocamento do traço T-II e T-III.

O traço T-V com $20 \%$ de areia natural e $80 \%$ de areia de britagem de rocha calcária, apresentou o mesmo padrão de deslocamento do traço T-II e T-III, com um maior deslocamento aos 10 min de que aos 15 min, mas alcançou um máximo de deslocamento $20 \%$ menor que o T-II e T-II, mesmo contendo uma quantidade maior de areia de britagem que os demais apresentou uma deformação um pouco menor que T-IV devido as rugosidade desta areia. Os resultados dos ensaios das argamassas no tempo de 15 min para T-I apresenta um início de deformação aos 3,6 mm de deslocamento, T-II, e T-III aos 5,6 mm de deslocamento, e T-IV com 7,9 mm e T-V com 6,8 mm totalizando um espaço de $4 \mathrm{~mm}$ de diferença de T-I, para T-V de desloca- 
mento para início da deformação e um final também de aproximadamente $4 \mathrm{~mm}$ de diferença, seguindo o mesmo padrão para as deformações aos 10 mim porém com deslocamentos maiores.

O comportamento reológico das argamassas é influenciado pela base sobre a qual a mesma for aplicada, o ensaio realizado sobre uma base lisa não aderente, como recomenda a norma, não oferece resistência ao deslizamento demonstrando uma situação ideal de aplicação da argamassa, podendo gerar resultados com algumas diferenças de aplicação desta argamassa em substrato real. Observou-se que a adição da areia de britagem nos traços T-IV e T-V provocou deslizamentos irregulares na base de vidro, pois a curva descrita apresenta saltos não uniformes atribuídos a diferença granulométrica e a forma e textura irregulares dos grãos da areia de britagem.

Foi realizado também o ensaio de densidade de massa e teor de ar incorporado das argamassas no estado fresco, conforme determina a norma NBR 13278[24] com repetição em três amostras, o resultado mostrado na Figura 7 é a média das três.

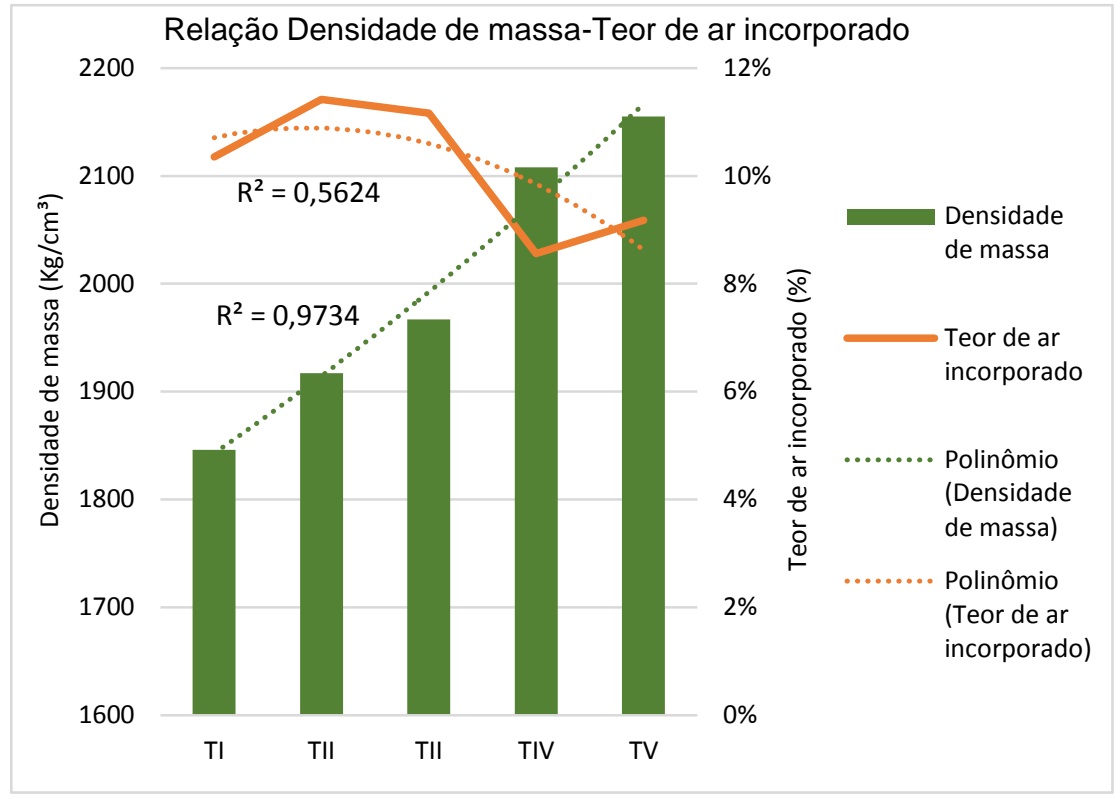

Figura 7: Densidade de massa e Teor de ar incorporado nas argamassas.

Na Figura 7 observa-se que a densidade de massa da argamassa no estado fresco aumenta conforme aumenta a quantidade de areia de britagem na argamassa, este aumento da densidade de massa é justificado pois a massa específica da areia de britagem é maior, aumentando a sua quantidade aumenta a densidade de massa.

O teor de ar incorporado calculado varia de $11 \%$ a $9 \%$ representando uma variação de $10,18 \%$ do maior índice em relação ao menor. Gonsalves [8] encontrou valores mais baixos que estes, seus índices variaram de $0,08 \%$ a 3,08\%, no entanto seus traços continham cal, e não continham aditivos. Para Gonçalves [8], o aumento dos teores de finos, cal e material pulverulento, aumentam o grau de empacotamento do conjunto agregado/aglomerante.

O aumento do teor de ar incorporado nas argamassas pode ser atribuído também ao uso do aditivo, conforme informações do fabricante [32], em composições de cimento/areia e aditivo, sem a cal foi detectado índices de teor de ar incorporado que variam de $9,8 \%$ a $8,1 \%$.

$\mathrm{O}$ alto teor de ar incorporado contribui no aumento da trabalhabilidade das argamassas, porém pode também ser a causa de porosidade excessiva em argamassas, permitindo o aumento de permeabilidade e infiltrações, que por sua vez contribuem com patologias nos revestimentos. O valor elevado do teor de ar incorporado pode contribuir para a aplicação da argamassa na execução dos revestimentos.

Foi realizado também o ensaio de retenção de água na argamassa no estado fresco, a NBR 13277 [33] determina que seja feita a pesagem do funil com argamassa para determinação da retenção da água aos 15 min de duração de sucção da bomba ligada, nesta pesquisa foram feitas três pesagens, possibilitando a leitura de três retenções de água aos $5 \mathrm{~min}$. $10 \mathrm{~min}$ e $15 \mathrm{~min}$, isto possibilitou a observação da constância e regularidade desta retenção. Na Tabela 9 estão descritos os valores encontrados no ensaio. 
Tabela 9: Retenção de água nas argamassas.

\begin{tabular}{|c|c|c|c|c|c|}
\hline Tempo t(min) & T-I & T-II & T-III & T-IV & $T-V$ \\
\hline \multicolumn{6}{|c|}{ Água retida em (\%) } \\
\hline 5 & 84 & 81 & 80 & 79 & 78 \\
\hline 10 & 82 & 78 & 77 & 76 & 75 \\
\hline 15 & 80 & 76 & 75 & 74 & 73 \\
\hline
\end{tabular}

Os valores apresentados na Tabela 9 variam de $84 \%$ a $80 \%$ na areia natural, e de $81 \%$ a maior retenção no T-II e 73\% a menor no T-V, que são compostos por areia de britagem, Gonçalves[8] obteve valores de $61,80 \%$ a $40,15 \%$ na areia natural e69,68\% e 47,89\% na areia de britagem. Observa-se que para o autor os traços compostos com areia de britagem tiveram uma retenção maior de água do que os traços compostos com areia natural.

Na Figura 8 estão representadas graficamente a retenção de água para cada argamassa no estado fresco.

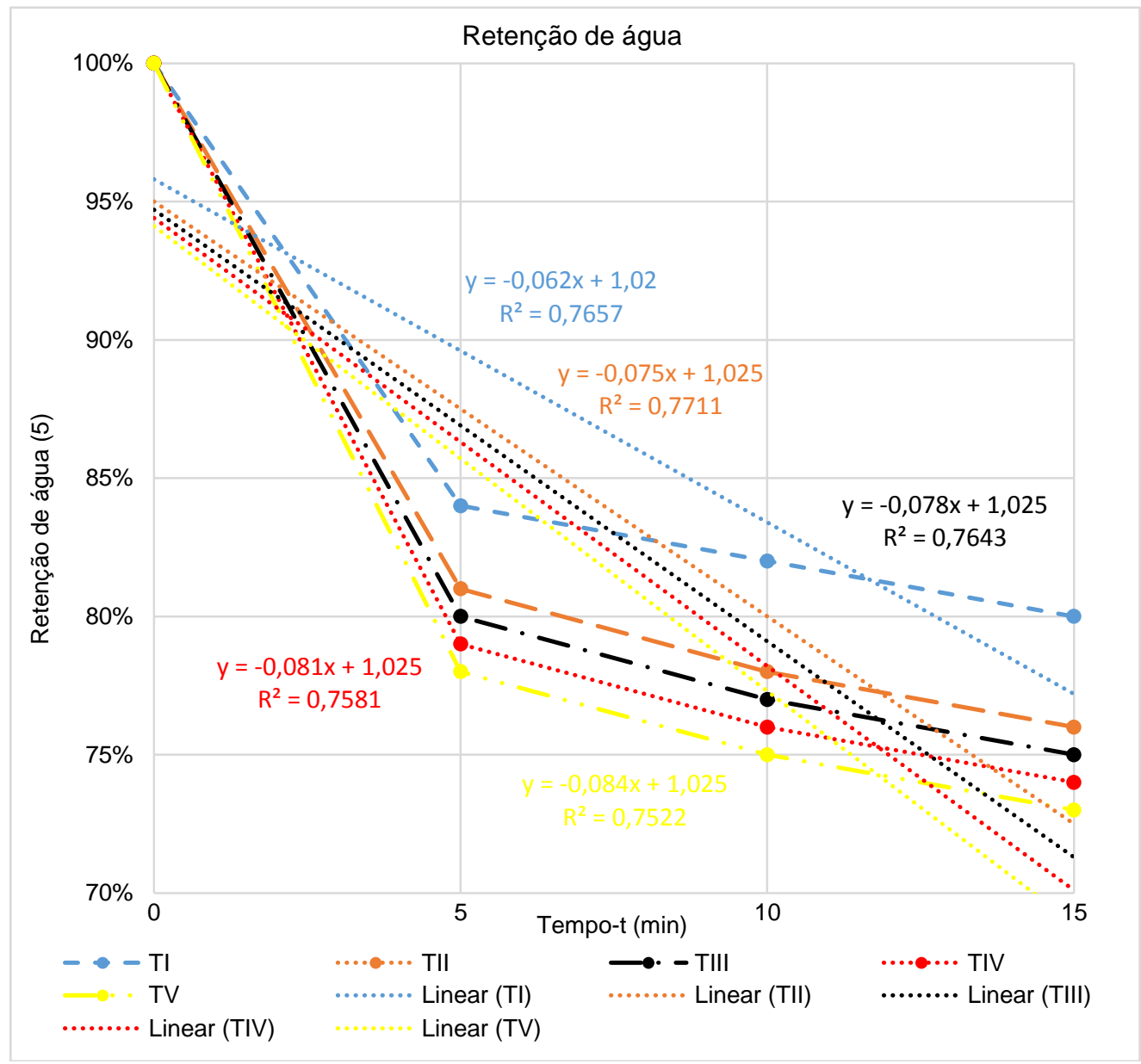

Figura 8: Gráfico de retenção da água com respectivas linhas de tendência.

Observa-se na Figura 8 que o perfil de T-I (100\% areia natural), apresenta o maior nível de retenção de água estando $4 \%$ acima do traço T-II (80\% de areia natural e $20 \%$ de areia de britagem de rocha calcária), sendo o maior índice de retenção aos $15 \mathrm{~min}$, nos demais traços quanto maior a quantidade de areia de britagem menor a retenção de água da argamassa. A diminuição da retenção de água é constante, não são constatados variações de leituras, caindo $3 \%$ do tempo de leitura 5 min para 10 min e $2 \%$ do tempo de leitura de 10 min para o tempo de $15 \mathrm{~min}$, nos quatro traços com areia de britagem.

Os valores apresentados na Tabela 9 variam de $84 \%$ a $80 \%$ na areia natural, e de $81 \%$ a maior retenção no T-II e 73\% a menor no T-V, que são compostos por areia de britagem. Gonçalves [8] obteve valores de $61,80 \%$ a $40,15 \%$ na areia natural e $69,68 \%$ a 47,89\% na areia de britagem, para o autor que usou a cal em 
sua pesquisa, os traços compostos com areia de britagem tiveram uma retenção maior de água do que os traços compostos com areia natural. $\mathrm{O}$ uso da cal nas composições aumenta a quantidade final de finos nas argamassas que contribuem para o aumento da retenção de água nas mesmas.

O aumento no teor de finos aumenta a relação água/cimento das argamassas, contudo nas argamassas de calcário o efeito é inverso, mostrando uma diminuição nos valores em relação a argamassa de referência usada na pesquisa [34], reforçando assim o resultado obtido nesta pesquisa com menor retenção de água para maior quantidade de areia de britagem de rocha calcária. A menor retenção de água pela argamassa diminui a sua consistência, este fato pode vir a prejudicar a mesma na hora da aplicação no substrato, pois terá a sua plasticidade também diminuída. No caso desta pesquisa foi adotado o uso do aditivo plastificante com o objetivo de amenizar os efeitos da falta da cal nas argamassas.

O R $\mathrm{R}^{2}$ mostrado no gráfico varia de 0,75 a 0,77 indicando que os modelos se ajustam bem as amostras, ou seja a confiabilidade da análise das amostras no ensaio varia de 75,22\% a 77,11\%.

Outra característica importante a ser analisada nas argamassas no estado fresco é a exsudação de água, ou seja, o quanto a argamassa perda de água nas primeiras quatro horas após o seu preparo, enquanto esta sendo aplicada no substrato.

No gráfico da Figura 9 está representada a evolução desta exsudação com a respectiva análise das suas linhas de regressão ao longo destas quatro horas.

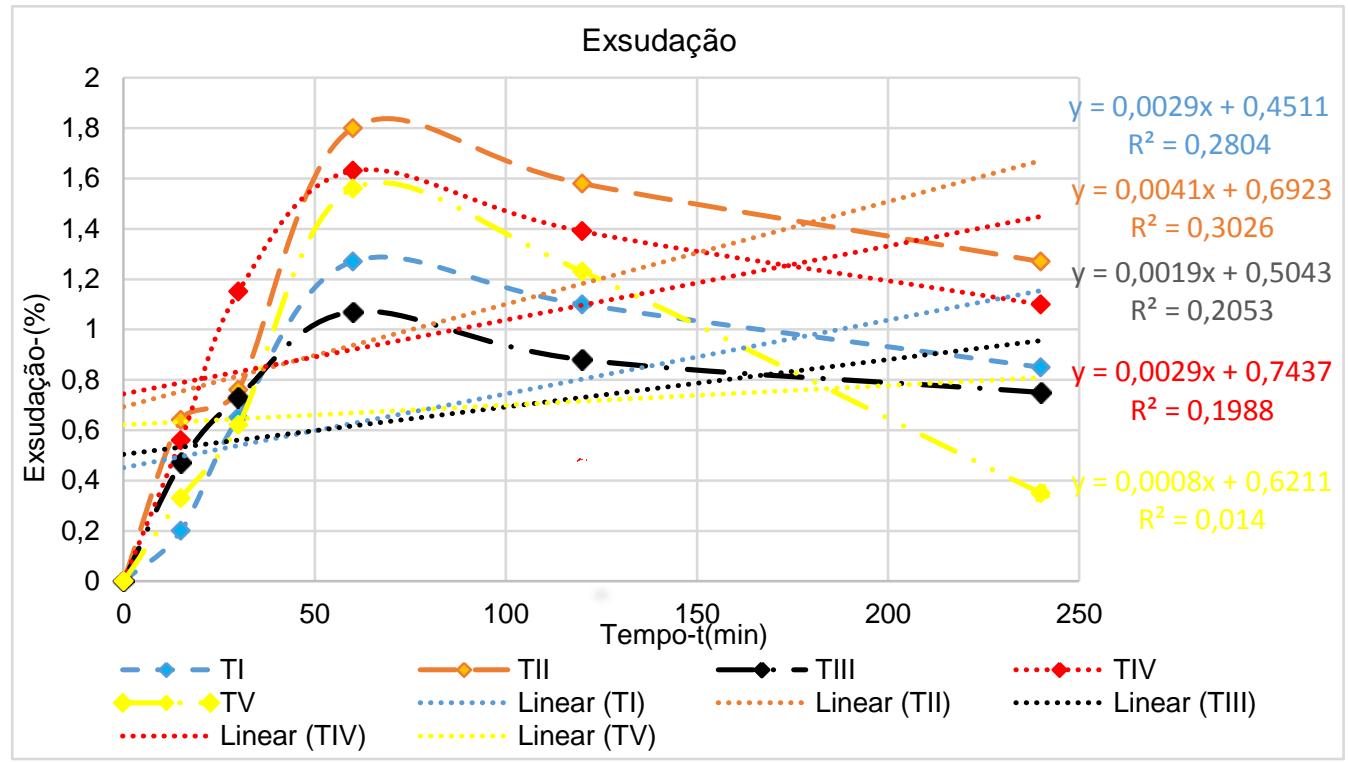

Figura 9: Gráfico de exsudação das argamassas com respectivas linhas de tendência.

Observa-se pelo gráfico da Figura 9 que todas as composições obtiveram um ápice de exsudação no tempo de $60 \mathrm{~min}$, independente da percentagem de areia de britagem de rocha calcária adicionada a composição, concluindo assim que o tempo necessário para a argamassa atingir o máximo de sua exsudação não depende da quantidade de areia de britagem usada na composição. Os resultados observados no não permitem traçar uma relação entre o aumento de areia de britagem e a diminuição da exsudação, existe sim uma relação entre o tempo de mistura e a diminuição da exsudação, a partir dos 60min esta começa a diminuir, acontecendo com menor intensidade dos $120 \mathrm{~min}$ aos $180 \mathrm{~min}$. Na Tabela 10 estão descritos os valores da exsudação lidas para cada traço nos tempos propostos para o ensaio.

Tabela 10: Exsudação da argamassa no estado fresco, valores lidos por períodos

\begin{tabular}{l|l|l|l|l|l}
\hline TEMPO T(MIN) & \multicolumn{5}{|l}{ (\%) EXSUDADA EM RELAÇÃO A ÁGUA DE AMASSAMENTO } \\
\hline & T-I & T-II & T-III & T-IV & T-V \\
\hline 15 & 0,20 & 0,64 & 0,47 & 0,56 & 0,33 \\
\hline 30 & 0,52 & 0,76 & 0,73 & 1,15 & 0,62 \\
\hline 60 & 1,27 & 1,80 & 1,07 & 1,63 & 1,56 \\
\hline 120 & 1,10 & 1,58 & 0,88 & 1,39 & 1,23 \\
\hline 240 & 0,85 & 1,27 & 0,75 & 1,10 & 0,35 \\
\hline Média & 0,814 & 1,21 & 0,7 & 1,166 & 0,818 \\
\hline
\end{tabular}


Analisando os resultados da Tabela 10 constata-se que a composição com maior percentagem de areia de britagem não é a que apresenta maior índice de exsudação aos $60 \mathrm{~min}$, está exsudação máxima ocorre no traço T-II, composto por $80 \%$ de areia natural e $20 \%$ de areia de britagem, seguido do T-IV, T-V, T-I e T-III. Os traços T-I, T-II, T-II, T-V se mantem praticamente constantes após os $60 \mathrm{~min}$, apenas o T-V sofre uma queda brusca dos 120 min para os 240 min. A maior média de exsudação ocorre com o traço T-IV, composto por $40 \%$ areia natural e $60 \%$ de areia de britagem.

A maior média de exsudação ocorre no traço T-II, sendo $73 \%$ maior que no traço T-III, que representa a menor média de exsudação das argamassas. A exsudação não apresentou um critério lógico em relação ao o aumento de areia de britagem de rocha calcária no traço.

As linhas de tendência no gráfico geraram um $\mathrm{R}^{2}$ baixo mostrando na regressão estatística que a variável dependente do ensaio não está sendo completamente explicada.

\section{CONCLUSÕES}

Com relação a granulometria, todos os traços atendem as recomendações e estão dentro das zonas utilizáveis inferior e superior segundo a NBR 7211 [28], sendo que o traço T-III (60\% de areia natural e $40 \%$ de areia de britagem de rocha calcária), encontra-se dentro do intervalo delimitado pelas zonas ótimas superior e inferior de granulometria, dos agregados miúdos, recomendado pela norma.

$\mathrm{Na}$ forma e textura dos grãos a areia de britagem apresenta grãos angulosos, irregulares e com rugosidade, enquanto a areia natural tem grãos arredondados e homogêneos. Esta diferença entre as areias nas misturas das argamassas provoca uma compensação granulométrica.

Nas argamassas no estado fresco T-II (80\% de areia natural e $20 \%$ de areia de britagem de rocha calcária), e T-III (60\% de areia natural e 40\% de areia de britagem de rocha calcária), apresentam um IC (índice de consistência) de T-II=273,52 mm e T-III=280,29 mm, observou-se que estas duas competições apresentaram a melhor a trabalhabilidade da argamassa.

O traço T-V (20\% de areia natural e $80 \%$ de areia de britagem de rocha calcária), apresenta a maior densidade de massa, porém com baixo teor de ar incorporado, o que leva a perda da trabalhabilidade da argamassa. O traço T-III (60\% de areia natural e $40 \%$ de areia de britagem de rocha calcária), apresenta o melhor índice de incorporação de ar, o que contribui para trabalhabilidade da argamassa.

Concluiu-se que as argamassas com areia de britagem de rocha calcária (T-II, T-III, T-IV, T-V), apresentaram melhor desempenho do que a argamassa somente com areia natural (T-I) nos seguintes índices: Índice de consistência; densidade massa da argamassa no estado fresco; teor de ar incorporado. Nas argamassas, dentre os traços de areia de britagem de rocha calcária, os que apresentaram melhor desempenho foram, T-III (60\% de areia natural e $40 \%$ de areia de britagem de rocha calcária) e T-IV (40\% de areia natural e $60 \%$ de areia de britagem de rocha calcária).

Conclui-se que a areia de britagem de rocha calcária é indicada para uso nas argamassa de revestimento. Ainda conclui-se que as argamassas estudadas nesta pesquisa, que que utilizam a areia de britagem de rocha calcária atendem aos critérios da NBR 13281 [35].

\section{AGRADECIMENTOS}

A UTFPR - Universidade tecnológica Federal do Paraná; ao IFSC - Instituto de Educação Ciências e Tecnologia de Santa Catarina; a Cimentos Votorantim; e cimentos Itambé.

\section{BIBLIOGRAFIA}

[1] CARASEK, H. “Argamassas”, In: Isaia, G.C. (ed.). Materiais de Construção Civil e Princípios de Ciência e Engenharia de Materiais, São Paulo, IBRACON, pp. 892-944, 2010.

[2] Editoria, ASSOCIAÇÃO NACIONAL DE ENTIDADESDE PRODUTORAS DE AGREGADOS PARA CONSTRUÇÃO CIVIL, http://www.anepac.org.br. Acessado em maio de 2015.

[3] SANKH, A. C., BIRADAR, P.M., NAGHATHAN, S.J., et al., "Recent trends in replacement of Natural sand with different alternatives", In: Proceedings of the International Conference on Advances in Engineering and Technology, pp. 59-66, 2014.

[4] SOUZA KAZMIERCZAK, C., ROSA, M., ARNOLD, D. C. M. "Influência da adição de filer de areia de britagem nas propriedades de argamassas de revestimento", Ambiente Construído, v. 16, n. 2, pp. 7-19, 2016. 
[5] CARASEK, H., ARAÚJO, R. C., CASCUDO, O., et al., "Parâmetros da areia que influenciam a consistência e a densidade de massa das argamassas de revestimento", Revista Matéria, v. 21 n. 3, pp.714-732, 2016.

[6] ARNOLD, D. C. M. Análise da influência da forma dos grãos nas propriedades das argamassa, Dissertação de M.Sc, UNISINOS. São Leopoldo, RS, Brasil, 2011.

[7] CORTES, D. D., KIM, H. K., PALOMINO, A. M., et al., "Rheological and mechanical properties of mortars prepared with natural and manufactured sands", Cement and Concrete Research, v. 38, n 10, pp. 1142-1147, 2008.

[8] GONÇALVES, N. S. Argamassa de revestimento de cimento, cal e areia britada de rocha calcária, Dissertação de M.Sc, UFPR, Curitiba, PR, Brasil, 2006.

[9] GUACELLI, P. A. G. Substituição da areia natural por areia de britagem de rochas basálticas para argamassas de revestimento, Dissertação de M.Sc., UEL, Londrina, PR, Brasil, 2010.

[10] GUACELLI, P. A. G., RISSON, D. B. DE S., CARBONARI, B. M. T. "Substituição de areia de extração por areia de britagem para argamassa de revestimento", In: XI SBTA - Simposio Brasieliro De Tecnologia das Argamassas, Porto Alegre, RS, Abr. 2015.

[11] ISHIKAWA, P. H., OLIVEIRA, P. L. "Propriedades da argamassa com areia artificial para revestimento de alvenaria", In: Congresso Português De Argamassas E Etics, APFAC, Coimbra, 2012.

[12] PANDOLFO, L. M., MASUERO, A. B. "Características das Areias de Basalto que Influenciam nas Propriedades das Argamassas”, In: SBTA - Simpósio Brasileiro De Tecnologia Das Argamassas, 2005. Florianópolis. Anais ANTAC, Florianópolis 2005.

[13] SANKH, A. C., BIRADAR, P.M., NAGHATHAN, S.J., et al., "Recent trends in replacement of Natural sand with different alternatives", In: Proceedings of the International Conference on Advances in Engineering and Technology, pp. 59-66, 2014.

[14] SILVA, N. G., BUEST, G. T., CAMPITELI, V. C. "Argamassas com areia britada: influência dos finos e da forma das partículas", In: VI SBTA - Simpósio Brasileiro De Tecnologia Das Argamassas, Florianópolis, pp. 11-22, 2005.

[15] BAUER, E. Revestimentos de argamassa: características e peculiaridades. Brasília, LEMUnB/Sinduscon DF, 2005.

[16] ANÔNIMO (2003), NBR NM 248: Agregados - Determinação da composição granulométrica. Rio de Janeiro, ABNT - Associação Brasileira de Normas Técnicas.

[17] ANÔNIMO (2006), NBR NM 45: Agregados - Determinação da massa unitária e do volume de vazios. Rio de Janeiro, ABNT - Associação Brasileira de Normas Técnicas.

[18] ANÔNIMO (2002), NBR NM 52: Agregado miúdo - Determinação de massa específica e massa específica aparente. Rio de Janeiro, ABNT - Associação Brasileira de Normas Técnicas.

[19] ANÔNIMO (2003), NBR NM 46: Agregado - Determinação do material fino que passa através da peneira 75 um por lavagem. Rio de janeiro, ABNT - Associação Brasileira de Normas Técnicas.

[20] ANÔNIMO (2006), NBR 6467: Agregado - Determinação do inchamento do agregado miúdo. Rio de Janeiro, ABNT - Associação Brasileira de Normas Técnicas.

[21] ANÔNIMO (2001), NBR NM 30: Agregado miúdo - Determinação da absorção de água. Rio de Janeiro, ABNT - Associação Brasileira de Normas Técnicas.

[22] ANÔNIMO (2001), NBR NM 49: Agregado miúdo - Determinação de impurezas orgânicas. Rio de Janeiro, ABNT - Associação Brasileira de Normas Técnicas.

[23] ANÔNIMO (2005), NBR13276: Argamassa para assentamento e revestimento de paredes e tetos - Preparo da mistura e determinação do índice de consistência. Rio de Janeiro, ABNT - Associação Brasileira de Normas Técnicas.

[24] ANÔNIMO (2005), NBR 13278: Argamassa para assentamento de paredes e revestimento de paredes e tetos - Determinação da densidade de massa e do teor de ar incorporado. Rio de Janeiro, ABNT - Associação Brasileira de Normas Técnicas.

[25] ANÔNIMO (2016), ASTM C 1506: Standard Test Method for Water Retention of Hydraulic CementBased Mortars and Plasters. ASTM - American Society For Testing And Materials. 
[26] ANÔNIMO (2010), NBR 15839: Argamassa de assentamento e revestimento de paredes e tetos caracterização reológica pelo método squeeze flow. Rio de Janeiro, ABNT - Associação Brasileira de Normas Técnicas.

[27] ANÔNIMO (1982), MR-6 RILEM: Tendency of water separate from mortars. France: RILEM - International Union of Testing and Research Laboratories for Materials and Strutures.

[28] ANÔNIMO (2005), NBR 7211: Agregados para concreto - Especificação. Rio de Janeiro, ABNT Associação Brasileira de Normas Técnicas.

[29] DRAGO, C., VERNEY, J. C. K., PEREIRA, F. M. Efeito da utilização de areia de britagem em concretos de cimento Portland, Rem: Revista Escola de Minas, v. 62, n. 3, pp. 399-408, 2009.

[30] ARAUJO, R. C., MELO, L. A., SILVA, D. G., et al., "Efeito da natureza e da forma das partículas de areias de diferentes mineralogias na consistência da argamassas", In: XI SBTA - Simpósio brasileiro de tecnologia da argamassa, pp. 28-30, Porto Alegre, RS, Brasil, abril 2015.

[31] TRISTÃO, F. A. Influência dos Parâmetros Textuais das Areias nas Propriedades das Argamassas Mistas de Revestimento, Dissertação de M.Sc, UFSC, Florianópolis, SC, Brasil, 2005.

[32] Vedacit, VEDALIT, http://www.vedacit.com.br/produtos/vedalit. Acessado em maio de 2016.

[33] ANÔNIMO (2005), NBR 13277: Argamassa para assentamento e revestimento de paredes e tetos Determinação da retenção de água. Rio de Janeiro, ABNT - Associação Brasileira de Normas Técnicas.

[34] ANGELIM, R. R., ANGELIM, S. C. M., CARASEK, H. "Influência da adição de finos calcários, silicosos e argilosos nas propriedades das argamassas e dos revestimentos", In: V Simpósio Brasileiro de Tecnologia das Argamassas, pp. 401-416, São Paulo, SP, Brasil, 2003.

[35] ANÔNIMO (2005), NBR 13281: Argamassa para assentamento e revestimento de teto - Requisitos. Rio de Janeiro, ABNT - Associação Brasileira de Normas Técnicas. 